\title{
EFFECTS OF DIETHYL ETHER ANAESTHESIA AND SURGERY ON CARBOHYDRATE AND FAT METABOLISM IN MAN
}

\author{
Tsutomu Oyama, M.D. and T. Takazawa, M.D."
}

MANY PAPERS HAVE BEEN PUBLISHED concerning the effects of ether anaesthesia on carbohydrate metabolism. However, no report has been published of its effect on human growth hormone and on plasma insulin levels. The possibility that ether anaesthesia may interfere with the action of insulin has been suggested by Henneman and Vandam, ${ }^{1}$ but this has been questioned by Greene. ${ }^{2}$ The present study was undertaken to explore the effects of ether anaesthesia alone on the carbohydrate and fat metabolism by determining plasma growth hormone, insulin, blood glucose, free fatty acids (FFA), and cortisol, and to compare it with the effects when an operation is superimposed upon anaesthesia.

\section{Materials and Method}

Twenty male patients, ranging in age from 22 to 56 years, were the subjects of the study. All underwent elective operations. None had hepatic, renal, or endocrine disease, nor a history of steroid therapy (Table I). All received pentobarbital (Nembutal ${ }^{\circledR}$ ), $100 \mathrm{mg}$, by mouth one and a half hours before operation, followed by meperidine (Demerol ${ }^{\circledR}$ ), $35 \mathrm{mg}$, and atropine, $0.5 \mathrm{mg}$ intramuscularly one hour before operation. Anaesthesia was induced with nitrous oxide $2 \mathrm{~L} / \mathrm{min}$ and oxygen

TABI.E I

Patients and Operations (20 male pts.)

\begin{tabular}{cccl}
\hline \hline Subjects & Age & $1 \mathrm{t}(\mathrm{Kg})$ & Operations \\
\hline 1 & 44 & 62.0 & Oral plastic op. \\
2 & 22 & 54.0 & Repair of shoulder \\
3 & 50 & 49.0 & Gastrectony \\
4 & 52 & 48.0 & Exploratory laparotomy \\
5 & 56 & 63.0 & Prostatectomy \\
6 & 50 & 59.5 & Cholecystectomy \\
7 & 52 & 53.0 & Incision of abscess \\
8 & 53 & 43.0 & Artificial anus \\
9 & 32 & 63.5 & Skin grafting \\
10 & 38 & 52.5 & Rectal amputation \\
11 & 54 & 45.5 & Gastrectomy \\
12 & 45 & 56.0 & Maxillectomy \\
13 & 18 & 58.5 & Spinal fusion \\
14 & 51 & 61.0 & Gastrectomy \\
15 & 17 & 60.5 & Bone grafting \\
16 & 46 & 60.0 & Cholecystectomy \\
17 & 32 & 46.5 & Gastrectomy \\
18 & 54 & 57.0 & Gastrectomy \\
19 & 49 & 57.5 & Gastrectomy \\
20 & 21 & 60.0 & Skin grafting \\
\hline
\end{tabular}
Japan.

"Department of Anaesthesia, Hirosaki University School of Medicine, Hirosaki, Aomori-Ken, 
$2 \mathrm{~L} / \mathrm{min}$; ether was added from a Copper Kettle vaporizer. After 10 to 15 minutes of anaesthesia, endotracheal intubation was carried out under succinylcholine chloride $40 \mathrm{mg}$. For maintenance the depth of anaesthesia was kept at plane $1-2$ of the third stage as judged by clinical signs and by occasional electroencephalographic monitoring. Tubocurarine (3-9 mg) was used for muscle relaxation during the operation. Respiration was assisted intermittently throughout the procedure. Anaesthesia lasted at least 45 minutes in each case. Normal saline 100-300 ml was infused until 15 minutes after the beginning of the operation, then low molecular weight dextran $500 \mathrm{ml}$ was infused throughout the rest of the operation. Blood was transfused when needed. Arterial $\mathrm{Po}_{2}, \mathrm{PCO}_{2}$, and $\mathrm{pH}$ were determined by means of the Astrup ultra-micro method using a Severinghaus electrode.

Eight blood samples were obtained from each patient: (1) the first, ten minutes before induction of anaesthesia; (2) the next three 15, 30, and 45 minutes after induction of anaesthesia but before start of the operation; (3) another three 5-10, 30 , and 60 minutes after the start of the operation; and (4) lastly after conclusion of the anaesthesia when the patient was awake in the recovery room. For each sample five $\mathrm{ml}$ of venous blood were drawn into a syringe previously rinsed with heparin. The plasma was separated within 30 minutes. One $\mathrm{ml}$ of plasma was frozen at $-20^{\circ} \mathrm{C}$ for storage; it was thawed within one month, prior to radioimmunoassay for growth hormone and insulin. One $\mathrm{ml}$ of plasma was kept at $4^{\circ} \mathrm{C}$ for analysis of cortisol and free fatty acids (FFA) [= nonesterified fatty acids (NEFA) ]; and $0.2 \mathrm{ml}$ of blood was used to measure blood glucose.

Determinations of plasma growth hormone ( $\mathrm{HGH}$ ) were done according to the method of Schalch. ${ }^{3}$ The analysis of plasma insulin was made after the method of Morgan and Lazarow. ${ }^{4}$ These double antibody methods were based on the principle of radioimmunoassay utilizing $\mathrm{I}^{125}$. Duplicate determinations were made of all specimens and the mean values were taken. The recovery rate for HGH and insulin were 98 per cent and 94 per cent respectively which indicates reliable analysis.

The plasma cortisol concentration was measured by radiostereoassay after Murphy $y^{5}$ using $\mathrm{H}^{3}$-corticosterone and a Beckman liquid scintillation counter. The blood glucose was measured by the method of Somogyi ${ }^{6}$ and plasma FFA was determined by the colorimetric method of Dumcombe. ${ }^{7}$

\section{Results}

\section{Growth hormone}

Control plasma growth hormone (HGH) level in the 20 premedicated patients, immediately before induction of anaesthesia was $1.5 \pm 0.3 \mathrm{~m} \mu \mathrm{g} / \mathrm{ml}($ mean $\pm \mathrm{sE}$ ) which was within normal limits (less than $5.0 \mathrm{~m} \mu \mathrm{g} / \mathrm{ml}$ ). After 15 minutes of ether anaesthesia it had increased slightly to $1.7 \pm 0.3 \mathrm{~m} \mu \mathrm{g} / \mathrm{ml}$. At thirty minutes it was found to be elevated significantly to $3.2 \pm 0.6 \mathrm{~m} \mu \mathrm{g} / \mathrm{ml}(p<0.02)$, and at 45 minutes it had increased still further to $3.9 \pm 1.1 \mathrm{~m} \mu \mathrm{g} / \mathrm{ml}(p<0.05)$. These results are illustrated in Table II and Figure 1. The plasma HGH concentration decreased slightly to $3.8 \pm 1.0 \mathrm{~m} \mu \mathrm{g} / \mathrm{ml}$ within $5-10$ minutes after the start of the operation but rose significantly to the peak value of $10.2 \pm 2.0 \mathrm{~m} \mu \mathrm{g} / \mathrm{ml}(p<$ 
Plasma Levels of $\mathrm{HGH}$, Insulin, Cortisol, Glucose FFA in the GOE Group
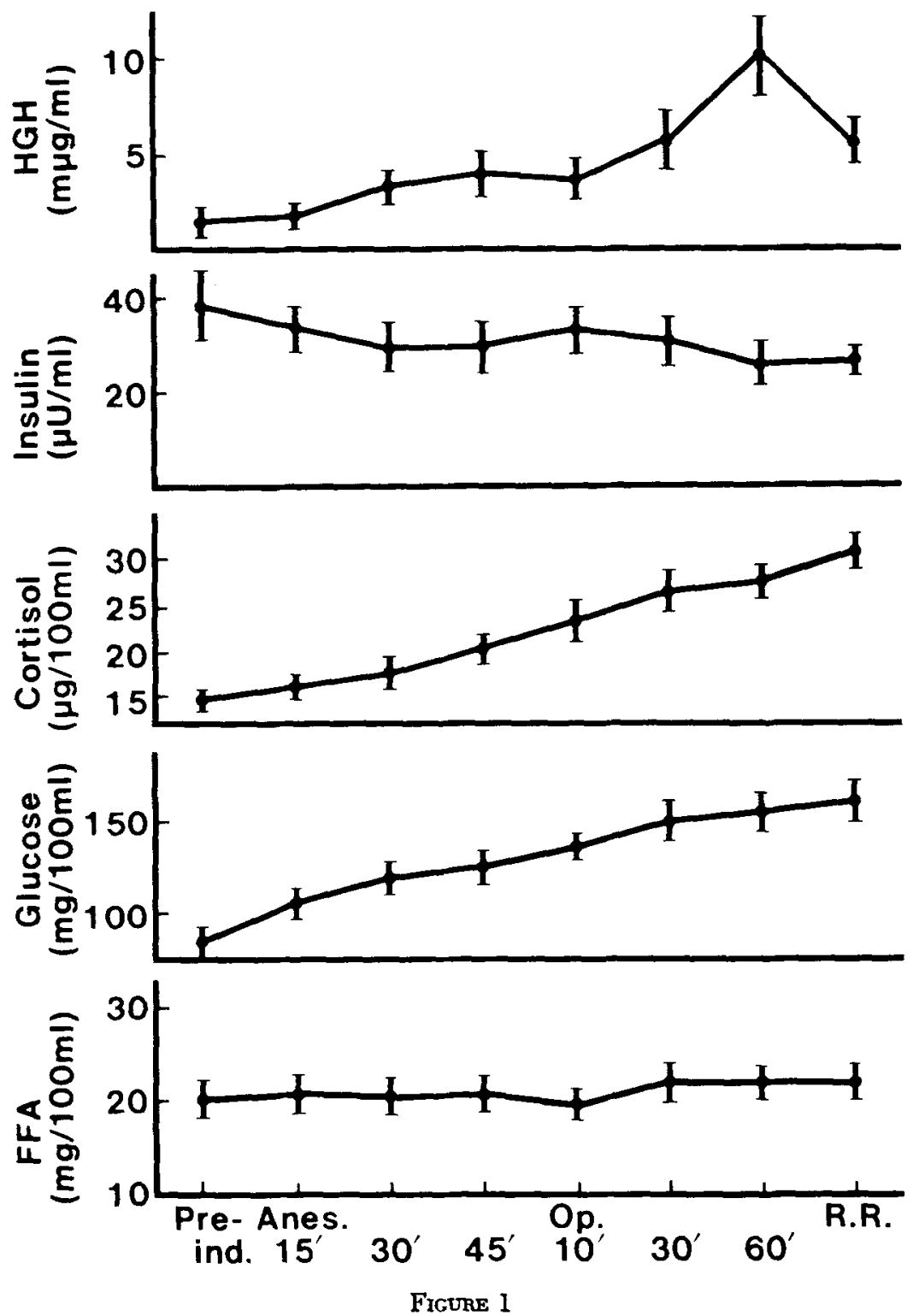
TABLE II

Plasma hah Levels During Ether Anaesthesia and Surgery $(\mathrm{m} \mu \mathrm{g} / \mathrm{ml})$

\begin{tabular}{|c|c|c|c|c|c|c|c|c|}
\hline \multirow[b]{2}{*}{ Subjects } & \multicolumn{8}{|c|}{ Time (min) } \\
\hline & $\begin{array}{l}\text { Pre- } \\
\text { ind. }\end{array}$ & Anes. $15^{\prime}$ & $30^{\prime}$ & $45^{\prime}$ & Op. $10^{\prime}$ & $30^{\prime}$ & $60^{\prime}$ & RR \\
\hline 1 & 0.7 & 1.0 & 1.8 & 1.1 & 2.1 & 5.7 & 7.6 & 9.5 \\
\hline 2 & 1.2 & 1.0 & 2.2 & 1.4 & 1.4 & 5.3 & 8.1 & 7.6 \\
\hline 3 & 4.1 & 4.6 & 8.2 & 18.9 & 12.7 & 9.9 & 12.7 & 8.4 \\
\hline 4 & 1.1 & 2.7 & 3.4 & 3.0 & 1.9 & 4.3 & 3.1 & 1.0 \\
\hline 5 & 1.0 & 0.9 & 1.7 & 2.2 & 2.0 & 2.1 & 4.4 & 3.1 \\
\hline 6 & 4.6 & 1.5 & 2.7 & 1.7 & 1.3 & 7.9 & 15.6 & 11.9 \\
\hline 7 & 0.5 & 1.0 & 1.0 & 0.5 & 0.8 & 5.8 & 10.5 & 12.8 \\
\hline 8 & 2.5 & 4.7 & 6.6 & 7.8 & 7.0 & 6.0 & 20.3 & 9.3 \\
\hline 9 & 0.2 & 1.4 & 9.8 & 15.5 & 15.3 & 10.7 & 7.0 & 5.6 \\
\hline 10 & 1.2 & 0.4 & 0.4 & 0.3 & 0.6 & 2.1 & 10.2 & 2.6 \\
\hline 11 & 1.7 & 1.3 & 2.3 & 1.0 & 1.0 & 1.3 & 10.7 & 1.5 \\
\hline 12 & 1.0 & 1.0 & 0.7 & 1.0 & 1.0 & 0.7 & 0.7 & 2.7 \\
\hline 13 & 0.7 & 1.0 & 1.0 & 1.3 & 1.0 & 2.7 & 4.0 & 1.0 \\
\hline 14 & 1.3 & 2.0 & 3.0 & 3.3 & 2.0 & 1.7 & 4.7 & 1.3 \\
\hline 15 & 1.0 & 1.0 & 1.3 & 1.3 & 10.0 & 30.0 & 38.3 & 16.7 \\
\hline 16 & 3.0 & 3.7 & 3.3 & 1.7 & 1.3 & 1.3 & 3.0 & 1.7 \\
\hline 17 & 1.3 & 1.3 & 1.3 & 1.3 & 1.3 & 4.3 & 23.3 & 8.0 \\
\hline 18 & 2.0 & 2.0 & 3.0 & 2.0 & 2.0 & 5.7 & 14.3 & 9.3 \\
\hline 19 & 1.0 & 1.7 & 6.7 & 11.0 & 10.0 & 6.0 & 3.7 & 1.3 \\
\hline 20 & 0.7 & 0.7 & 2.7 & 1.0 & 1.0 & 1.3 & 2.7 & 0.7 \\
\hline$\overline{\text { Mean }}$ & 1.5 & 1.7 & 3.2 & 3.9 & 3.8 & 6.7 & 10.2 & 5.8 \\
\hline SF & 0.3 & 0.3 & 0.6 & 1.1 & 1.0 & 1.4 & 2.0 & 1.0 \\
\hline$p$ & & NS** & $<0.021^{*}$ & $<0.05^{*}$ & $<0.05^{*}$ & $<0.01^{*}$ & $<0.00^{*} *$ & $<0.002$ \\
\hline
\end{tabular}

*Statistically significant compared with preinduction.

**Statistically not significant.

0.001 ) at one hour after the start of the operation. It decreased slightly but still remained elevated $(5.8 \pm 1.0 \mathrm{~m} \mu \mathrm{g} / \mathrm{ml})$ in the recovery room when the patient had recovered.

\section{Insulin}

The control pre-induction plasma insulin level in 19 patients was $37.7 \pm 6.7$ $\mu \mathrm{U} / \mathrm{ml}$ (mean $\pm \mathrm{SE}$ ) which was slightly higher than normal $(5-35 \mu \mathrm{U} / \mathrm{ml})$. It decreased to $30.3 \pm 4.4 \mu \mathrm{U} / \mathrm{ml} 45$ minutes after ether anaesthesia, but this was not a significant change. The lowest insulin level in plasma $(25.6 \pm 3.8 \mu \mathrm{U} / \mathrm{ml})$ was noted at 1 hour after start of the operation. This was a statistically significant decrease from control value $(p<0.02)$ (Table III and Figure 1 ).

\section{Blood glucose}

The mean control pre-induction blood glucose level in 20 patients was $85 \pm 4$ $\mathrm{mg} / 100 \mathrm{ml}$ ( $\pm \mathrm{SE}$ ); after 15 minutes, 30 minutes, and 45 minutes of ether anaesthesia values were $105 \pm 6,121 \pm 5$, and $124 \pm 5 \mathrm{mg} / 100 \mathrm{ml}$ respectively $(p<$ $0.001)$; and after 10 minutes from incision $132 \pm 6 \mathrm{mg} / 100 \mathrm{ml}(p<0.001)$, after 30 minutes $150 \pm 8 \mathrm{mg} / 100 \mathrm{ml}(p<0.001)$, after 1 hour $155 \pm 8 \mathrm{mg} / 100 \mathrm{ml}$ $(p<0.001)$, and in the recovery room $161 \pm 8 \mathrm{mg} / 100 \mathrm{ml}(p<0.001)$ (Table IV and Figure 1). 
TABLE III

Plasma Insulin Levels During Ether Anaesthesia and Surgery ( $\mu U / \mathrm{ml})$

\begin{tabular}{|c|c|c|c|c|c|c|c|c|}
\hline \multirow[b]{2}{*}{ Subjects } & \multicolumn{8}{|c|}{ Time (min) } \\
\hline & $\begin{array}{l}\text { Pre- } \\
\text { ind. }\end{array}$ & Anaes. $1 \bar{o}^{\prime}$ & $30^{\prime}$ & $45^{\prime}$ & Op. $10^{\prime}$ & $30^{\prime}$ & $60^{\prime}$ & RR \\
\hline 1 & 82.8 & $37 . \overrightarrow{3}$ & 52.9 & 43.7 & 41.4 & 64.4 & 62.1 & 50.6 \\
\hline 2 & 46.0 & 43.7 & 41.4 & 18.4 & 52.9 & $34 . j$ & 23.0 & 32.2 \\
\hline 3 & 43.7 & 39.1 & 50.6 & 48.3 & 41.4 & 50.6 & 52.9 & 39.1 \\
\hline 4 & 20.7 & 25.3 & 39.1 & 34.5 & 48.3 & 32.2 & 11.5 & 29.9 \\
\hline 5 & 85.1 & 52.9 & 55.2 & 34.5 & 50.6 & 55.2 & 43.7 & 39.1 \\
\hline 6 & 87.4 & 50.6 & 78.2 & 80.5 & 55.2 & 41.4 & 48.3 & 32.2 \\
\hline 7 & 4.6 & 13.8 & 11.5 & 9.2 & 9.2 & 18.4 & 9.2 & 9.2 \\
\hline 8 & 16.1 & $11 . \overline{2}$ & 18.4 & 9.2 & 18.4 & 27.6 & 23.0 & 13.8 \\
\hline 9 & 9.2 & $11 . j$ & $9 . \overline{2}$ & 6.9 & 2.3 & 6.9 & 6.9 & 16.1 \\
\hline 10 & 50.0 & 41.7 & 33.3 & 28.3 & 38.3 & 10.0 & 20.0 & 28.3 \\
\hline 11 & 6.7 & 11.7 & 16.7 & 26.7 & 11.7 & 11.7 & 11.7 & 33.3 \\
\hline 12 & 16.7 & 20.0 & 5.0 & 11.7 & 5.0 & 11.7 & 25.0 & 20.0 \\
\hline 13 & 66.7 & 66.7 & 5.0 & 45.0 & 45.0 & 66.7 & 8.3 & 5.0 \\
\hline 14 & 45.0 & 36.7 & 8.3 & 16.7 & 41.7 & 6.7 & 15.0 & 15.0 \\
\hline 1.5 & 80.0 & 66.0 & 66.0 & 66.0 & 88.0 & 88.0 & 00.0 & 50.0 \\
\hline 16 & 5.0 & 8.3 & 26.7 & 33.3 & 10.0 & 6.7 & 15.0 & 26.7 \\
\hline 17 & 13.3 & 20.0 & 21.7 & 18.3 & 150 & 18.3 & 15.0 & 40.0 \\
\hline 18 & 21.5 & 25.0 & 23.1 & $19 . \overline{5}$ & 20.0 & 23.5 & 28.1 & 20.0 \\
\hline 19 & 15.6 & 23.0 & 19.7 & 25.0 & 25.0 & 18.6 & 18.0 & 21.0 \\
\hline Mean & 37.7 & 333.2 & 30.6 & 30.3 & 32.6 & 31.2 & 25.6 & 27.4 \\
\hline SE & 6.7 & $\underset{4.3 * 3}{4.3}$ & $\begin{array}{r}4.8 \\
N S *\end{array}$ & $\begin{array}{r}4.4 \\
4 *^{*}\end{array}$ & 5.0 & 5.3 & 3.8 & 2.9 \\
\hline$p$ & & $\lambda S^{*}$ & NS* & $N S^{*}$ & NS* & $N S^{*}$ & $<0.02$ & $\mathrm{NS}^{*}$ \\
\hline
\end{tabular}

*Statistically not significant.

TABI.E IV

Blood Glucose Concentration During Ether Anaesthesia and Sukgery (mg/100 ml)

\begin{tabular}{|c|c|c|c|c|c|c|c|c|}
\hline \multirow[b]{2}{*}{ Subjects } & \multicolumn{8}{|c|}{ Time $(\min )$} \\
\hline & $\begin{array}{l}\text { Pre- } \\
\text { ind. }\end{array}$ & Anaes. $1 \bar{b}^{\prime}$ & $30^{\prime}$ & $4 \bar{s}^{\prime}$ & Op. $10^{\prime}$ & $30^{\prime}$ & $60^{\prime}$ & $\mathrm{RR}$ \\
\hline 1 & 90 & 82 & 106 & 90 & 142 & 126 & 106 & 116 \\
\hline 2 & 136 & 126 & 160 & 108 & 158 & 216 & $\begin{array}{l}176 \\
176\end{array}$ & 176 \\
\hline 3 & 116 & 138 & 128 & 130 & 132 & 176 & 174 & 188 \\
\hline 4 & 102 & 148 & 96 & 108 & 114 & 132 & $\begin{array}{l}198 \\
198\end{array}$ & 178 \\
\hline 5 & 106 & 112 & 108 & 126 & 146 & 140 & 142 & 120 \\
\hline 6 & 80 & 130 & 140 & 126 & 186 & 138 & 154 & 168 \\
\hline 7 & 72 & 144 & 150 & $12 ; 2$ & 96 & 156 & 174 & 148 \\
\hline 8 & 100 & 134 & 138 & 122 & 138 & 200 & 182 & 182 \\
\hline 9 & 62 & 74 & 142 & 164 & 112 & 112 & 1.52 & 258 \\
\hline 10 & 58 & 40 & 58 & 116 & 174 & 168 & 156 & 182 \\
\hline 11 & 80 & 90 & 94 & 94 & 103 & 164 & 167 & 135 \\
\hline 12 & 81 & 109 & 122 & 131 & 156 & 159 & 206 & 169 \\
\hline 13 & 85 & 103 & 128 & 147 & 128 & 116 & 103 & 140 \\
\hline 14 & 75 & 106 & 153 & 181 & 181 & 244 & 234 & 188 \\
\hline 15 & 67 & 94 & 98 & 94 & 98 & 124 & 121 & 130 \\
\hline 16 & 70 & 89 & 112 & 128 & 102 & 128 & 130 & 100 \\
\hline 17 & 96 & 103 & 120 & 105 & 138 & 165 & 165 & 177 \\
\hline 18 & 72 & 81 & 103 & 91 & 103 & 128 & 128 & 181 \\
\hline 19 & 76 & 83 & 134 & 142 & 113 & 101 & 123 & 168 \\
\hline 20 & $7 \overline{5}$ & 116 & 122 & 111 & 122 & 103 & 102 & 116 \\
\hline Mean & 85 & $10 \pi$ & 121 & 124 & 132 & 150 & & \\
\hline$S E$ & 4 & 6 & $\overline{5}$ & i & 6 & 8 & 8 & 8 \\
\hline & & $<0.002^{*}$ & $<0.001^{*}$ & $<0.001^{*}$ & $<0.001 *$ & $<0.001^{*}$ & $<0.001^{*}$ & \\
\hline
\end{tabular}

*Statistically significant compared with preinduction. 
TABLE V

Plasma ffa Levels During Ether Anaesthesia and Surgery (mg/100 ml)

\begin{tabular}{|c|c|c|c|c|c|c|c|c|}
\hline \multirow[b]{2}{*}{ Subjects } & \multicolumn{8}{|c|}{ Time (min) } \\
\hline & $\begin{array}{l}\text { Pre- } \\
\text { ind. }\end{array}$ & Anaes. $15^{\prime}$ & $30^{\prime}$ & $45^{\prime}$ & Op. $10^{\prime}$ & $30^{\prime}$ & $60^{\prime}$ & RR \\
\hline 1 & 16.6 & 19.8 & 18.7 & 18.7 & 13.0 & 19.3 & 14.8 & 14.5 \\
\hline 2 & 17.8 & 14.7 & 20.1 & 10.8 & 19.2 & 16.8 & 14.2 & 16.8 \\
\hline 3 & 31.8 & 40.4 & 35.3 & 38.5 & 23.4 & 30.0 & 33.5 & 35.3 \\
\hline 4 & 38.4 & 32.2 & 31.3 & 38.2 & 37.8 & 28.4 & 32.0 & 35.9 \\
\hline$\overline{5}$ & 27.7 & 27.7 & 31.6 & 28.6 & 24.6 & 31.6 & 29.5 & 29.2 \\
\hline 6 & 19.7 & 25.8 & 34.4 & 38.1 & 39.8 & 35.0 & 27.0 & 30.1 \\
\hline 7 & 31.6 & 37.2 & 31.0 & 28.1 & 31.6 & 34.5 & 35.0 & 39.5 \\
\hline 8 & 21.7 & 21.2 & 28.0 & 18.0 & 21.7 & 27.0 & 29.5 & 20.1 \\
\hline 9 & 15.8 & 15.8 & 16.4 & 12.7 & 17.1 & 19.9 & 18.4 & 14.0 \\
\hline 10 & 32.4 & 31.5 & 31.0 & 33.9 & 32.3 & 34.2 & 38.7 & 31.0 \\
\hline 11 & 20.0 & 19.5 & 9.3 & 21.7 & 14.6 & 18.0 & 13.0 & 17.4 \\
\hline 12 & 16.7 & 12.4 & 11.2 & 11.8 & 21.0 & 17.9 & 10.5 & 21.7 \\
\hline 13 & 11.8 & 13.6 & 13.0 & 11.8 & 8.7 & 18.6 & 27.3 & 28.9 \\
\hline 14 & 18.6 & 18.6 & 12.4 & 21.1 & 18.0 & 18.0 & 22.2 & 26.0 \\
\hline 15 & 24.2 & 24.2 & 19.8 & 22.9 & 13.0 & 19.1 & 13.2 & 25.3 \\
\hline 16 & 22.9 & 22.9 & 18.4 & 18.6 & 15.5 & 17.0 & 18.6 & 15.0 \\
\hline 17 & 4.6 & 6.8 & 11.2 & 10.2 & 9.6 & 9.9 & 13.3 & 8.7 \\
\hline 18 & 12.4 & 15.5 & 14.9 & 14.0 & 11.8 & 10.5 & 12.7 & 8.7 \\
\hline 19 & 12.1 & 13.6 & 13.3 & 12.1 & 15.5 & 17.4 & 17.1 & 12.7 \\
\hline 20 & 8.7 & 10.5 & 12.8 & 12.4 & 8.4 & 15.2 & 15.0 & 13.6 \\
\hline Mean & 20.3 & 21.2 & 20.7 & 21.1 & 19.8 & 21.9 & 21.8 & 22.2 \\
\hline $\mathrm{SE}$ & 1.9 & 2.0 & 1.9 & 2.2 & 2.0 & 1.7 & 1.9 & 2.1 \\
\hline$p$ & & $\mathrm{NS}^{*}$ & $\mathrm{NS}^{*}$ & NS* & NS* & $\mathrm{NS}^{*}$ & $\mathrm{NS}^{*}$ & NS* \\
\hline
\end{tabular}

*Statistically not significant.

TABLE VI

Plasma Cortisol Levels During Ether Anaesthesia and Surgery ( $\mu \mathrm{g} / 100 \mathrm{ml}$ )

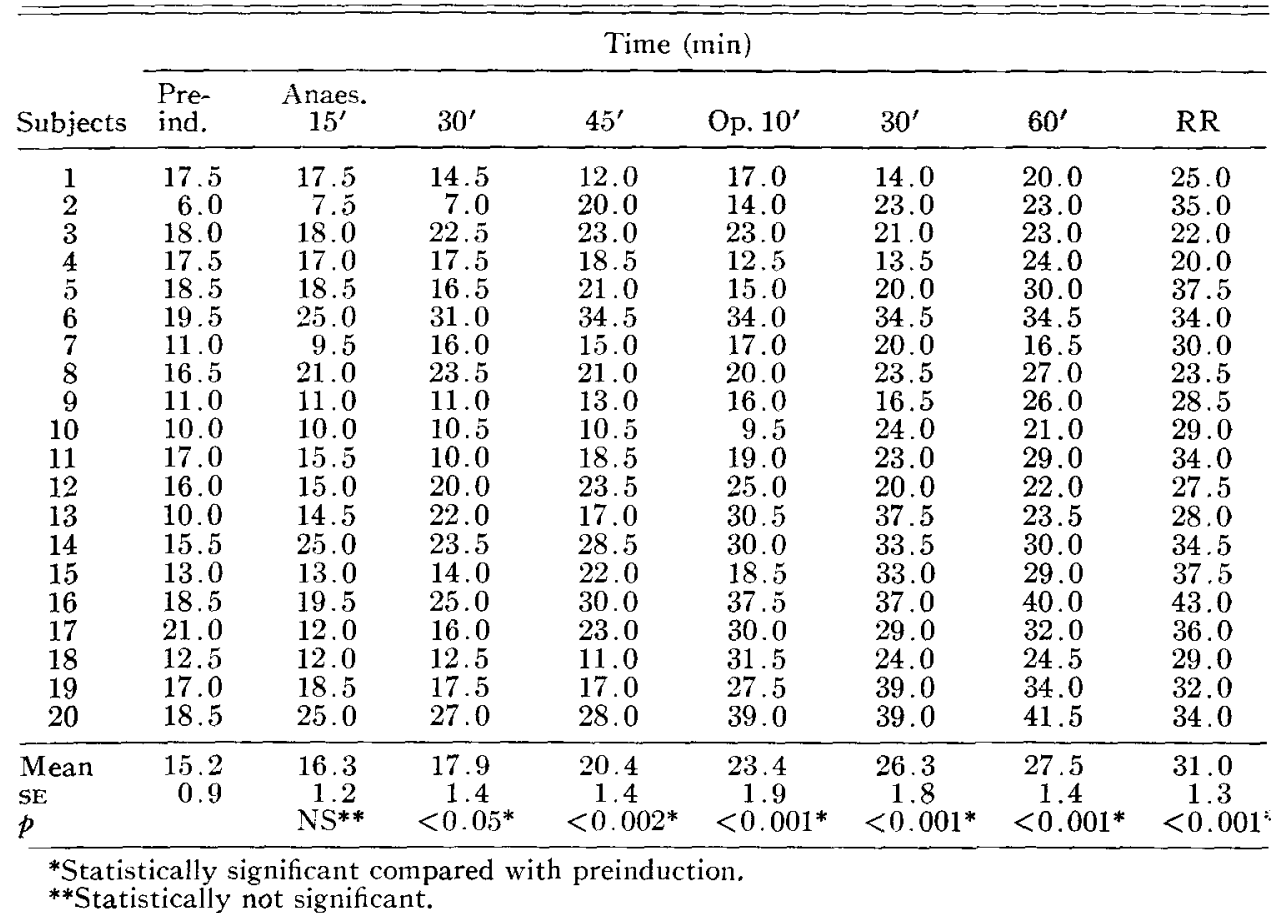


Free fatty acids (FFA)

The control plasma FFA level just before induction of anaesthesia in 20 patients was $20.3 \pm 1.9$ ( $\pm \mathrm{sE}$ ) $\mathrm{mg} / 100 \mathrm{ml}$. It increased slightly to $21.1 \pm 2.2 \mathrm{mg} / 100 \mathrm{~m}$ ] after 45 minutes of ether anaesthesia. There were no demonstrable variations during anaesthesia and operation (Table $V$ and Figure 1).

\section{Cortisol}

The mean control plasma cortisol level was $15.2 \pm 0.9 \mu \mathrm{g} / \mathrm{ml}$ ( $\pm \mathrm{SE}$ ). After 15 minutes of ether anaesthesia it was $16.3 \pm 1.2 \mu \mathrm{g} / \mathrm{ml}$, after 30 minutes $17.9 \pm 1.4$ $\mu \mathrm{g} / \mathrm{ml}(p<0.05)$, and after 45 minutes $20.4 \pm 1.4 \mu \mathrm{g} / \mathrm{ml}(p<0.002)$. Plasma cortisol concentration further increased to $27.5 \pm 1.4 \mu \mathrm{g} / \mathrm{ml}(p<0.001) 1$ hour after start of the operation, and in the recovery room reached $31.0 \pm 1.3 \mu \mathrm{g} / \mathrm{ml}$ (Table VI).

\section{Discussion}

Our data demonstrate that control plasma growth hormone levels in patients premedicated with pentobarbital, meperidine, and atropine was within normal limits (less than $5 \mathrm{~m} \mu \mathrm{g} / \mathrm{ml}$ ). Diethyl ether anaesthesia for 45 minutes significantly increased blood HGH levels from 1.5 to $3.9 \mathrm{~m} \mu \mathrm{g} / \mathrm{ml}$. It had risen distinctly at 30 minutes after start of the operation and the peak value was reached at 1 hour after incision $(10.2 \mathrm{~m} \mu \mathrm{g} / \mathrm{ml})$, after which it decreased in the recovery room. Thus, the levels of plasma HGH during the course of anaesthesia and surgery did not increase gradually, but consisted of one peak which was distinctly different from that of cortisol.

Our findings of a rise in plasma HGH levels during operation coincide with those of others. ${ }^{3,8-11}$ They reported that plasma HGH level reached the highest value about 1 hour after start of surgery and it gradually decreased to pre-operative level from 2 to several hours later. However, these authors have estimated plasma HGH levels only during operation, and no determinations were made during anaesthesia alone; therefore, they have failed to evaluate the effects of the anaesthetic on plasma HGH. Schalch ${ }^{3}$ and Charters ${ }^{10}$ found the degree of elevation of plasma HGH during operation was approximately the same regardless of the type of anaesthetic agent used. It is well known that diethyl ether anaesthesia increases plasma norepinephrine concentration in man. ${ }^{13}$ Bunker ${ }^{14}$ has postulated that many metabolic disturbances of ether anaesthesia including glucose intolerance ${ }^{13.18}$ and elevation of non-esterified fatty acids ( NFFA $=$ FFA), citrate, pyruvate, and ketones may be related to increased circulating epinephrine or norepinephrine. ${ }^{15}$ A decrease in utilization of infused glucose and glucose intolerance has been reported to occur with ether. ${ }^{18}$ But the interpretation of the reported data was challenged by Greene.2

Growth hormone of the anterior pituitary is an anabolic hormone which increases uptake and synthesis of amino acids. Growth hormone has also diabetogenic and anti-insulin effects, in that it reduces peripheral utilization and uptake of glucose, decreases glucose tolerance, and increases retention of glycogen. ${ }^{12}$ It enhances mobilization of fatty acids from adipose tissue and increases FFA in blood. Therefore, the effect of growth hormone on blood glucose cannot be ignored. 
Insulin promotes the rate of glucose penetration into the cell. Thereby, all pathways of glucose disposal are stimulated. It is known that plasma insulin level is not appreciably changed in diabetic patients, ${ }^{16}$ however, some workers observed that in severe diabetic patients or juvenile diabetic subjects the blood insulin levels are decreased. ${ }^{17}$ We found a tendency for blood insulin levels to fall during ether and surgical stress. This also might contribute to the observed elevation of blood glucose during ether anaesthesia and surgery. In patients suffering from diabetes mellitus, growth hormone exerts a diabetogenic effect. Therefore, the large elevation of plasma growth hormone and the fall in blood insulin level are not considered to be favorable for diabetic patients.

Variation in blood FFA level was not demonstrable during the procedures, which coincided with others. ${ }^{3}$ It is difficult to speculate why blood FFA level was relatively constant in spite of increased growth hormone which mobilized FFA from tissue to blood. Blood level of FFA is influenced not only by the production of FFA, but also the utilization.

\section{Summary and Conclusion}

The present study was undertaken to explore in 20 male surgical patients the effects of ether anaesthesia alone on the carbohydrate and fat metabolism by determining plasma growth hormone, insulin, blood glucose, free fatty acids (FFA), and cortisol, and to compare them with the effects of anaesthesia associated with operation. Determination of plasma growth hormone (HGH), insulin, cortisol, free fatty acids (FFA), and blood glucose were made simultaneously before induction of diethyl ether anaesthesia, after induction of anaesthesia for 45 minutes, during, and after conclusion of the operation.

Plasma HGH concentrations during ether anaesthesia showed a significant elevation, rising remarkably 1 hour after the start of the operation. A relative decrease in plasma insulin level and increases in blood glucose were noted during ether anaesthesia and operation. But no demonstrable variation of the blood FFA level was found during anaesthesia alone or during operation. Plasma cortisol levels significantly increased stepwise during anaesthesia and operation. Our observations would suggest that the increased blood level of growth hormone, lowered plasma insulin concentration, and elevated blood cortisol play a part in the increase of blood glucose during ether anaesthesia and operation in man.

\section{RÉSUMÉ}

Nous avons entrepris l'étude ci-contre pour préciser, chez 20 opérés mâles, les effets de l'anesthésie à l'ether seul sur le métabolisme des hydrates de carbone et des graisses, sur l'augmentation plasmatique des hormones, de l'insuline, de la glycémie, des acides gras libres (FFA) et du cortisol et les comparer avec les effets associés de l'anesthésie et de l'opération. Nous avons déterminé l'augmentation plasmatique d'hormone, ( HGH), linsuline, le cortisol, les acides gras libres et la glycémie en même temps avant l'induction de l'anesthésie à l'éther diéthylique, après 45 minutes d'anesthésie, au cours et après l'opération.

$\mathrm{Au}$ cours de l'anesthésie à l'éther, nous avons constaté une augmentation sig- 
nificative des hormones plasmatiques (HGH) s'élevant de façon marquée une heure après le début de l'opération; au cours de l'anesthésie à l'éther et de l'opération. l'insuline plasmatique à diminué et la glycémie a augmenté. Par contre, il n'y a pas eu de variation évidente des (FFA) acides gras libres ni durant lanesthésie seule, ni durant l'opération. Les taux de cortisol plasmatique se sont élevés de façon assez marquée au cours de l'anesthésie et de l'opération. Nos observations nous incitent à penser que l'augmentation des hormones sanguines, la diminution du taux d'insuline plasmatique, la concentration élevée de cortisol sanguin jouent un rôle dans l'augmentation de la glycémie au cours de l'anesthésie à l'éther et au cours de l'opération chez l'humain.

\section{REFERENCES}

1. Hennemai, D. H. \& Vandam, L. D. Effect of Epinephrine, Insulin, and Tolbutamide on Carhohydrate Metabolism during Ether Anaesthesia. Clin. Pharmacol. Ther. 1: 694 $(1960)$.

2. Greene, N. M. Inhalation Anesthetics and Carbohydrate Metabolism. Baltimore: Williams \& Wilkins Co (1963).

3. Schalch, D. S. The Influence of Physical Stress and Exercise on $\mathrm{GH}$ and Insulin Secretion in Man. J. Lab. Clin. Med. 69: 256 (1967).

4. Morcian, C. R. \& Lazarow, A. Inmunoassay of Insulin: Two Antibody System. Diabetes. 12: 115 (1963).

5. Murphy, B. E. P. Some Studies of the Protein-Binding of Steroid and Their Application to the Routine Micro and Ultro-Micro Measurement of Various Steroids in the Body Fluids by Competition Protein-Binding Radioassay. J. Clin. Endocrin. 27: 973 (1967).

6. Sonrocyi, M. Notes on Sugar Determination. J. Biol. Chem. 195: 19 (1952).

7. Dumcomes, W. G. The Colorimetric Microdetermination of Longchain Fatty Acids. Biochem. J. 88: 7 (1963).

8. Grick, S. M.; Roth, J.; Yalow, R. S.; \& Berson, S. A. The Regulation of Growth Hormone Secretion. Rec. Progr. Hormone Res. 24: 241 (1965).

9. Ross, H.; Jonnstone, I. D. A.: Welmon, T. A.; \& Whight, A. D. Effect of Abdominal Operation on Glucose Tolerance and Serum Levels of Insulin, GH. and Hydrocortisone. Lancet. 2: 563 ( 1966 ).

10. Charter, A. C.; Odell, W. D.; \& Thompson, J. C. Anterior Pituitary Function during Surgical Stress and Convalescence. Radioimmumoassay Measurements of Blood TSH, LH, FSH, and Growth Hormone. J. Clin. Endocr. 29: 63 ( 1969).

11. Ketter, H.; Powell, D.; \& Unger, R. H. Growth Hormone Response to Surgical Stress. Clin. Res, 14:65 (1966).

12. Greenwood, F. C.; Laxdon, J.; \& Stamp, T. C. B. The Plasma Sugar, Free Fatty Acid, Cortisol, and Growth Hormone Response to Insulin. I. In Control Subjects. J. Clin. Invest. 45: 429 (1966).

13. Hennemann, D. H. \& Vandam, L. D. The Metabolic Consequences of Epinephrine and Insulin Administered during Ether Anesthesia in Man. Anesthesiology. 19: 104 (1958).

14. Bunker, J. P. Neuroendocrine and Other Effects on Carbohydrate Metabolism during Anesthesia. Anesthesiology. 24: 515 (1963).

15. Henneman, D. H. \& Bunker, J. P. Effects of General Anesthesia on Peripheral Blood Levels of Carbohydrate and Fat Metabolites and Serum Inorganic Phosphorus. J. Pharmacol. Exp. Ther. 133: 253 (1961).

16. Johansex, K. \& Hansen, A. P. High 24-Hour Level of Serum Growth Hormone in Juvenile Diabetics. Brit. Med. J. 2: 356 (1969).

17. Allison, S. P.; Prowse, K.; \& Chamberlain, M. J. Failure of Insulin Response to Glucose Load during Operation and After Myocardial Infarction. Lancet. 1: 481 (1967).

18. Drucker, W. R.; Costley, C.; Stults, R.; Holden, W. D.; Craig, J.; Miller, M.; Hormaxi, N.; \& Woodward, H. Studies of Carbohydrate Metabolism during Ether Anesthesia; Effect of Ether on Glucose and Fructose Metabolism. Metabolism 8: 827 (1959). 